\title{
STUDENT TEACHERS' BELIEFS ON ORAL CORRECTIVE FEEDBACK IN ENGLISH LANGUAGE TEACHING
}

\author{
CRENÇAS DE PROFESSORES ESTAGIÁRIOS ACERCA DO USO DE \\ FEEDBACK CORRETIVO ORAL NO ENSINO DE LÍNGUA INGLESA
}

Jaime José de Vasconcelos Neto Lídia Amelia de Barros Cardoso

Recebido em: 15/10/2020

Aprovado em: 12/11/2020

\begin{abstract}
Oral Corrective Feedback (OCF) in a foreign language classroom is an essential factor for language learning because, according to Platt and Brooks (1994 Apud Shrum and Glisan, 2010), it helps students to make themselves understood and also in the development of strategies that help them to interact using the language. Taking into consideration the relation between theory and practice, Corrective Feedback (CF)'s importance and what student teachers might think about it, the questions that we aim to answer with this research are: (1) how OCF takes place in two different classroom settings, EFL and K-12, and (2) what are student teachers' beliefs on it. For this research, two Letras-Inglês undergraduate student teachers who were taking the teaching practicum course at Universidade Federal do Ceará had two of their classes observed and videotaped. Then, the two student teachers answered some questions related to the use of OCF. The results show that there were more occurrences of OCF strategies in the K-12 school setting than in the EFL course, being explicit feedback the most used strategy. These findings seem to indicate that the student teachers tend to use explicit/direct strategies more than the implicit/indirect. Also, it suggests that the student teachers interviewed see recast as the most effective strategy while they see explicit correction as the least effective strategy. Also, they believe that students should not be over corrected, because it could lead them to be upset or afraid of speak. On the contrary, both student teachers see explicit correction (the OCF strategy they most used) as one strategy that "put the student on the spot". Lastly, both of them consider displaying students' mistakes on the board as an effective strategy of correction, even when it is the case of dealing with oral production.
\end{abstract}

Keywords: Oral Corrective Feedback. Student teachers. EFL

RESUMO: É sabido que Feedback Corretivo Oral (FCO) é considerado um fator indispensável no ensino de uma língua estrangeira, pois, segundo Platt e Brooks (apud SHRUM E GLISAN, 2010), além de ajudar os alunos a se fazerem entender, isso também possibilita o desenvolvimento de estratégias que os ajudam a interagir através da linguagem. Levando em consideração a relação entre teoria e prática, a importância do FC e as possíveis crenças dos professores estagiários a respeito disso, as questões que essa pesquisa pretende responder são: (1) como ocorre o uso de Feedback Corretivo (FC) em dois contextos de ensino diferentes, em uma escola e um curso de inglês, e (2) quais crenças os professores estagiários tem a respeito de FCO. Para esta pesquisa de análise qualitativa, dois professores estagiários, alunos do curso de Letras - Inglês na Universidade Federal do Ceará, tiveram duas de suas aulas dadas durante o estágio de regência observadas e gravadas, com foco no uso das estratégias de FC Oral. Além disso, eles foram entrevistados após os procedimentos metodológicos de observação e gravação a respeito do uso dessas estratégias. Os resultados mostraram índice maior de ocorrências de estratégias de correção oral no contexto da escola quando comparado as ocorrências no contexto do curso livre de Inglês, sendo a correção explicita a estratégia mais utilizada. Os índices de ocorrência observados parecem indicar que os professores estagiários tendem a usar mais estratégias explicitas/diretas que implícitas/indiretas. Os resultados também sugerem que os professores estagiários entrevistados veem reformulação como a estratégia de correção mais eficaz e correção explicita como a estratégia de correção menos eficaz. Os professores estagiários revelaram acreditar que 
correção em excesso pode fazer com que os alunos se sintam chateados ou com medo de falar. Por outro lado, ambos os professores estagiários veem correção explicita (a estratégia mais utilizada por eles) como uma estratégia que expõe os alunos. Por fim, ambos também consideram escrever os erros dos alunos no quadro como uma estratégia eficaz, mesmo quando lidando com produção oral.

Palavras-chave: Feedback Corretivo Oral. Professores Estagiários. Ensino de Língua Inglesa.

\section{INTRODUCTION}

Corrective feedback (CF) is a topic that has always gotten teachers' attention and that has raised a lot of discussions on the Second Language Acquisition Field. Ur (2009, p. 242) defines feedback as "information that is given to the learner about his or her performance of a learning task, usually with the objective of improving this performance."

A considerable amount of research has been done about Classroom Assessment (ANGELO, T. A., \& CROSS, K. P.,1993; ELLIS, 2009; LYSTER, 2007), but most of them focus on students' or teachers' beliefs on CF. In her research on 'EFL teacher's choices for different types of CF", Menti (2009) observed and videotaped the classes of five teachers and interviewed them, aiming to discuss which factors led the teachers previously observed to use Oral Corrective Feedback (OCF) strategies or not inside an EFL classroom. Another interesting finding apparently concerning not only the use of CF strategies but its relationship with teachers' beliefs on it, is one that Kurkgöz et al. (2015) discuss. According to them, the OCF strategies that were most used by teachers in primary EFL classrooms in 'Turkey were not the ones that mostly led to uptake (students' responses to OCF strategies).

Also, the studies on this area usually investigate the beliefs on CF of teachers who are experts or even novices, and most of the times the beliefs student teachers have about it are neglected. Considering that, we decided to focus this research on student teachers' beliefs on OCF as a way to give an overview of their beliefs and what really happens inside an EFL classroom when considering CF.

For foreign language classrooms in which the main focus is communication, the OCF is an essential factor for language learning. According to Platt and Brooks (1994 Apud SHRUM AND GLISAN, 2010), OCF helps students to make themselves understood and also assists in the development of additional strategies that help them interact using the language. Despite of that, Lyster (2007) states that research has suggested that the use of feedback is not a high priority factor for teachers.

Taking into consideration this relation between theory and practice, OCF's importance and what student teachers might think about it, the objectives of this research are: (1) Explore how OCF takes place in two different classroom settings, EFL and $\mathrm{K}-12$, and (2) inquire what student teachers' beliefs on OCF are. The research conducted took place in two different settings, being one in an EFL upper basic course offered by Universidade Federal do Ceará (UFC) in the city of Fortaleza and one in a sixth grade in a private middle school located in the city of Pacajus.

\section{LITERATURE REVIEW}

Shrum and Glisan (2010, p. 283) divide classroom feedback into two types: "(1) error correction and (2) response to the content of the student's message (...)", the first one being related to the correction of mistakes, and the second one being more related to assessment of the whole message. Ur (2009) states that teachers could give assessment without correction. On the other hand, she also says that it is impossible for a teacher to make comments on students' mistakes without assessment.

When dealing with oral presentations, CF could be much more challenging, because teachers 
have to make decisions of correcting the mistake or let them go. Assuming this challenge, we are led to think that student teachers would benefit more if some questions could be taken into consideration when giving CF on an oral performance, such as:

"What is the primary focus?"

The conceptions the student teacher has about language will certainly influence the way $\mathrm{CF}$ is given on an oral performance or task. His/her conception of language could be focused on accuracy, which the main focus is usually correctness or fluency, which the main focus is usually fluency itself in communication (Harmer, 2013).

"How are the concepts error, mistake, and covert mistake understood?"

Although some people understand these two definitions as synonyms, they are seen as different terms in the Second Language Acquisition field. Bartram and Walton (2004), define mistake as something the learner has already learned but he is still having problems when using this information, and errors as something the learner is trying to use even though he or she have not learned how to use it yet. For example, if a learner already knows how to use the simple past structures, but he continues or eventually confuses its use, by not putting the right structure into practice, it would be considered a mistake. If a learner does not know how to use the simple past structures but tries to use it, without accuracy, it would be considered an error. Bartram and Walton (2004) call attention to the fact that these distinctions between error and mistake might be completely theoretical and really hard to be noticed and distinguished inside a classroom.

Another type of mistake which Bartram and Walton (2004) point out is the so-called "covert mistakes". These types of mistakes are when the learner uses the language correctly but what was said does not exactly convey the intended meaning. It may happen as a result of transfer from L1 to L2. For example, "I'm high" meaning "I'm tall". Grammatically, it is ok, but the message would certainly be misunderstood.

Differently, Edge (1997 Apud HARMER, 2013, p. 137) divides mistake into three categories: slips, errors and attempts. Slips are described as "mistakes that students can correct themselves once the mistake has been pointed out to them", errors are described as mistakes that the students "can't correct themselves - and which therefore need explanation", while attempts are described as a situation "when a student tries to say something but does not know yet the correct way of saying it".

Based on what Edge says about mistakes, a change to the question would go from "Is it an error or a mistake?" to "Is it a slip, an error or an attempt?". But, based on what Bartram and Walton point about errors and mistakes, it would be much more relevant to a teacher, when dealing with this kind of situation, asking him or herself: "Is it an important mistake?" or "Is the message clear?".

"How much CF am I giving to my students?"

Bartram and Walton (2004) claim that too much CF given in classroom could have students concerned about making mistakes - when mistakes are actually a sign that learning is taking place. On the contrary, teachers who never give CF in classroom could pass students the wrong idea that he or she does not know what he or she is doing.

\section{OCF strategies}

Another question that the teacher should ask himself/herself when giving CF on an oral performance is "What OCF strategy should I use in this particular case?" Lyster and Ranta (1997, Apud SHUM AND GLISAN, 2010) identified six types of teacher feedback: explicit correction, recast, clarification request, metalinguistic feedback, elicitation, and repetition. Brandl (2008), identifies these types of feedback as negative or error corrective feedback by dividing them into explicit/direct and implicit/indirect. Based on Brandl (2008) divisions of OCF strategies and Shum and Glisan (2010) definitions for each one of them, the two following tables (Table 1.1 and Table 1.2) provide explanations on it. 
Table 1.1: Indirect/Implicit OCF strategies

\begin{tabular}{|l|l|l|}
\hline $\begin{array}{l}\text { Indirect/Implicit feed- } \\
\text { back }\end{array}$ & \multicolumn{2}{|l|}{} \\
\hline Strategy & Definition & Examples \\
\hline Recast & $\begin{array}{l}\text { The teacher reformulates all or part of a stu- } \\
\text { dent's utterance minus the error. }\end{array}$ & $\begin{array}{l}\text { S: "I forget my cellphone" } \\
\text { T: "Oh, You forgot your } \\
\text { cellphone!" }\end{array}$ \\
\hline Clarification Request & $\begin{array}{l}\text { The teacher identifies a problem in either com- } \\
\text { prehensibility or accuracy or both: "Pardon } \\
\text { me" or "What do you mean by X?" }\end{array}$ & $\begin{array}{l}\text { S: "I am fifty years old" } \\
\text { T: "Pardon me?" } \\
\text { S: "I am fifteen Years old" }\end{array}$ \\
\hline
\end{tabular}

Source: Research data.

Table 1.2: Direct/Explicit OCF strategies

\begin{tabular}{|c|c|c|}
\hline Direct/Explicit Feedback & & \\
\hline Strategy & Definition & Examples \\
\hline Explicit Correction & $\begin{array}{l}\text { The teacher corrects the student, indicating cle- } \\
\text { arly that what the student said was incorrect }\end{array}$ & $\begin{array}{l}\text { S: "Yesterday I am at home" } \\
\text { T: "I was at home. Remember you } \\
\text { are talking about the past." }\end{array}$ \\
\hline Metalinguistic Feedback & $\begin{array}{l}\text { The teacher makes comments or asks questions } \\
\text { about the form of the student's utterance } \\
\text { without providing the correct form. These } \\
\text { comments indicate that there is an error so- } \\
\text { mewhere }\end{array}$ & $\begin{array}{l}\text { S: "I am at home yesterday." } \\
\text { T: "How would you say it } \\
\text { in the past?" }\end{array}$ \\
\hline Elicitation & $\begin{array}{l}\text { The teacher repeats part of the student's utte- } \\
\text { rance and pauses to allow the student to com- } \\
\text { plete the utterance at the place where the error } \\
\text { occurred }\end{array}$ & $\begin{array}{l}\text { S: "Yesterday, I goed home late" } \\
\text { T: Yesterday I... } \\
\text { S: Yesterday, I went home late }\end{array}$ \\
\hline Repetition & $\begin{array}{l}\text { The teacher repeats the student's erroneous ut- } \\
\text { terance, usually changing the intonation to } \\
\text { highlight the error }\end{array}$ & $\begin{array}{l}\text { S: "I have two beautifuls dogs" } \\
\text { T: "Do you have two beautifuls } \\
\text { dogs?" }\end{array}$ \\
\hline
\end{tabular}

Source: Research data.

\section{METHODOLOGY}

For this research, two student teachers taking two different teaching practicum courses at the undergraduate course Letras- Ingles (UFC) were recruited. One of them was taking Estágio III: Ensino das habilidades comunicativas da Lingua Inglesa, in which the setting was an English course offered by UFC in the city of Fortaleza. The other student teacher was taking Estágio IV: Ensino da Lingua Inglesa em escolas de Nivel Fundamental e Médio, in which the context was a private middle school in the city of Pacajus. The criteria used to choose the student teachers was their agreement to be observed, their availability to take part in the investigation and the possibility of observing and recording student teachers' behavior in the dynamic environment of two different classroom settings.

The data collection for this research consisted of three stages. In the first stage, the two student teachers were asked to answer a questionnaire with questions that related to their previous experiences as language learners/teachers.

The second stage of this research led to two classroom observations. For this stage, the student teachers were observed and videotaped, focusing on their uses of OCF strategies during the classes. The student teachers were not aware about the main focus of the classroom observations, since the fact of letting them know in advance or during this stage could interfere their teaching strategies concerning the use of OCF.

Lastly, in the third stage, the two student teachers answered a semi structured interview about the CF used (see section 4.2). In addition, the student teachers were asked to watch video segments from their own classes, recorded during the second stage. Since the focus of this research are student teachers' beliefs on OCF, the video segments showed during the final interview focused spe- 
cifically on the occurrences in which the uses of the strategies were evidenced or in moments in which OCF lacked. They were asked to reflect about the video segments and to comment.

\subsection{Participants}

The participants in this study were two Letras-Inglês undergraduate student teachers taking the teaching practicum course at Universidade Federal do Ceará. The student teacher A (STA) is a 27year-old Brazilian male who has been teaching for around seven years. Most of his experience as an English teacher was in English courses, which is also the context in which he was observed for this research. The student-teacher B (STB) is a 22-year-old Brazilian male who has been teaching for 4 years. During this time, he had only taught in k-12 private and public school settings, which is also the context he was observed. Even though the student teachers knew that their classes were being recorded, they were not aware that the focus of these observations were the use of OCF.

\section{FINDINGS}

\subsection{Classroom Observation}

A total of two classes were observed for each participant, being the focus of these observations the use of OCF during the English Classes (see Table 4 for a more detailed comparison between the use of OCF strategies in the EFL setting and the K-12 setting). During the two classes observed and videotaped, all the six different types of corrective feedback strategies were used by STA. The feedback strategies are listed in terms of frequency, from the most used (17 times) to the least used (1 time). They are: explicit feedback, metalinguistic feedback, clarification request, elicitation, recast and repetition. ved.

The following table illustrates the frequency each strategy was used during the classes obser-

Table 2: Occurrences of OCF - EFL setting

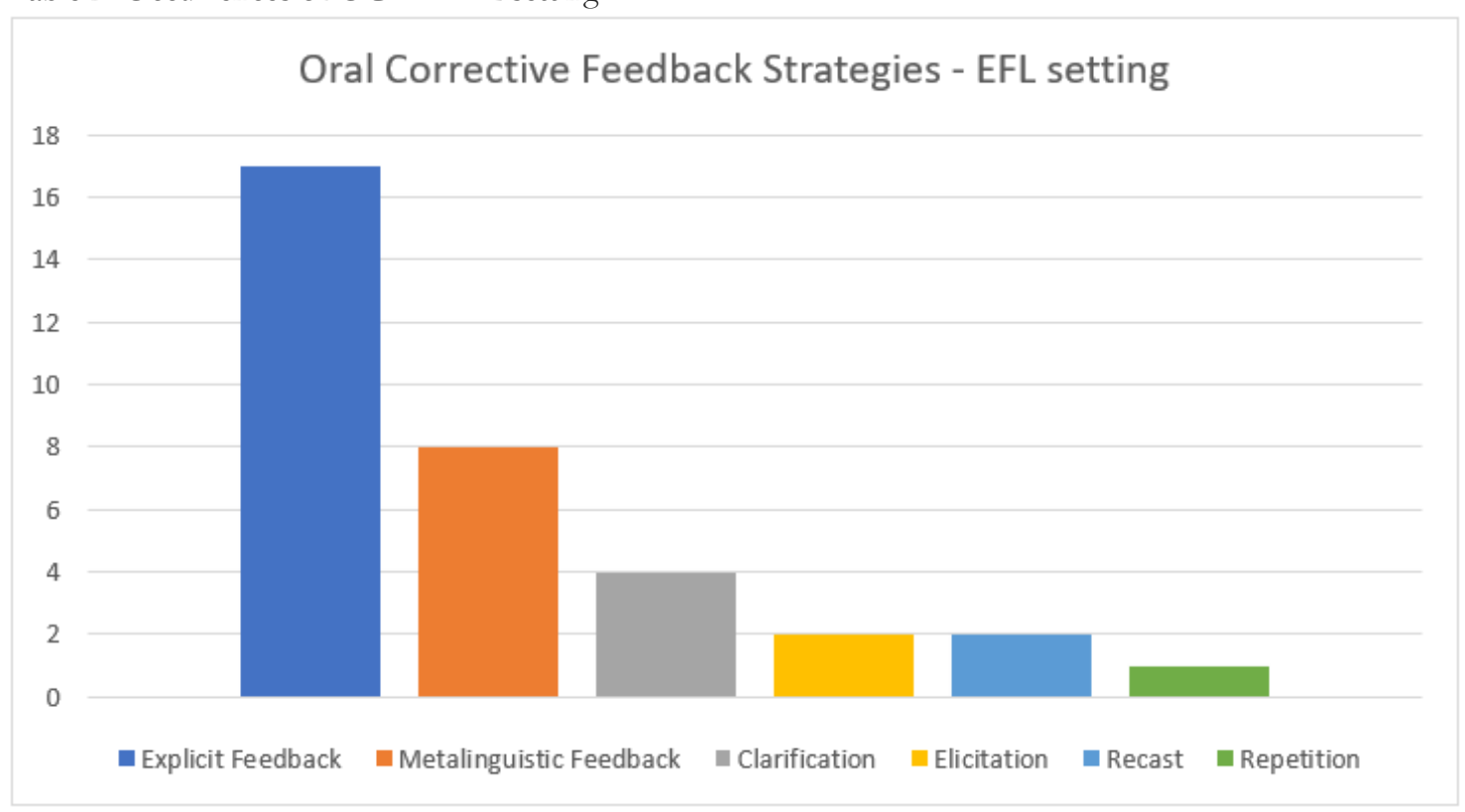

Source: Research data.

Evidence shows that $11,4 \%$ of the class time on the EFL setting was spent on the use of OCF. In order to calculate this amount of time, the movement that is taken into consideration is: 
teacher initiation, student response and feedback, as known as IRF movement (WELLS, 1993, apud GLISAN AND SHRUM, 2010, p. 82). The time spent on students' uptake (the answer students give for the corrective feedback) was also taken into consideration, when it happened.

The six different types of OCF strategies identified in STB's classes were namely, from the most used one (27 times) to the least used one (1 time): Explicit feedback, recast, metalinguistic feedback, clarification request, elicitation and repetition. Table 3 shows the frequency of occurrences identified during STB's classes.

Table 3: Occurrences of OCF - k-12 setting

\section{Oral Corrective Feedback Strategies - K-12 setting}

30

25

20

15

10
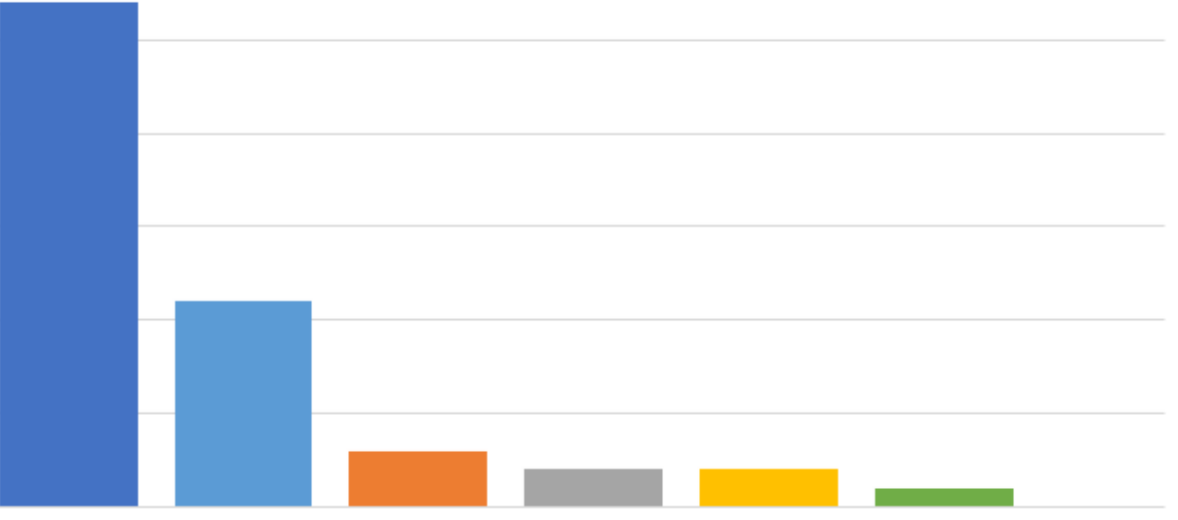

Explicit Correction $\square$ Recast $\square$ Metalinguistic Feedback $\square$ Clarification Request $\square$ Elicitation $\square$ Repetition

Source: Research data.

Evidence shows that $10,9 \%$ of the class time on the k-12 setting was spent on the use of corrective feedback. This amount of time was considered based on the IRF movement. Time used for uptake was also taken into consideration, when it happened.

\subsection{Interview}

The questionnaire used to guide this interview about the use of OCF strategies unfolded the following:

1. How do you see CF in an EFL classroom?

STA answer: [...] Eu tento de alguma maneira mostrar [o erro] por que eu acho que não adianta esconder. Você ficar... esconder o erro, que a pessoa não vai aprender, né? Vai achar que está falando certo, que tá fazendo aquela coisa certa, mas, no final, não tá. Então acho que é necessário, só que, eu tenho um certo MEDO, assim, né, não sei tratar muito bem essa parte da correção.

STB answer: It is essential for building up students' confidence and awareness of the target language's structure.

2. When a student makes a mistake, what helps you to decide if you are going to provide him/her CF or not? Which factors do you take into consideration when you have to decide it?

STA answer: Eu, particularmente, gosto sempre de corrigir gramática, né, erros gramaticais e ... depois de um tempo ensinando, né... passei a corrigir muito, é... coisa mais de contexto, de significação. De se o aluno conseguiu ser claro na frase dele, ou não, e pronuncia só quando divergir... divergia muito, né, 
da pronuncia padrão ou original [...].

STB answer: I try to judge the mistake as minor or major. If it is a major mistake, I give instant corrective feedback. If it isn't, I don't, obviously. However, if it is a minor but repetitive mistake, I also correct it.

When asked about what he considers major and minor mistakes, STB answered that major mistakes were the ones that interfere in communication, while minor mistakes were mistakes as "substitution of some phonemes, specially vowels". He completed his thought saying that "since the focus in schools is not for students to reach perfect pronunciation, I don't focus on that."

3. Which OCF strategies do you like to use most? Why?

STA answer: A estratégia que eu mais uso é botar a frase, qualquer coisa que estiver errado, na lousa né, no quadro, e pedir pra eles mesmos tentarem corrigir. Eu falo "ah, o que é que tem de errado aqui?" ou algo diferente, ou estranho. Isso pra algum erro gramatical, se for de pronuncia, aí já a gente tem que trabalhar com palavras, que sejam parecidas, né? Que tenham um som um pouco parecido. [A gente] Fala "oh, palavra tal assemelhasse com tal, não confundam, não vá falar assim, assim, é desse jeito".

STB answer: That one which rephrases what the student said correctly, I forgot the name... RECAST! In oral production, I think it helps students not to be afraid of speaking. In reading, I don't often use it. I prefer to have all students read out loud and as they read, I write on the board their pronunciation mistakes and correct them. If only one student is reading for the whole class, I adopt the same strategy except that I don't use the board for that.

4. Which OCF strategies you don't like to use most? Why?

STA answer: Eu não gosto muito de botar os alunos pra [se] corrigirem entre si, né, o peer assessment. Eu geralmente gosto de eu mesmo corrigir, lá na lousa mesmo, quadro. Não costumo muito usar os próprios alunos pra ficarem 'se corrigindo'.

STB answer: I don't like to keep correcting as they speak because it might upset them.

In addition, a video in which the six types of OCF strategies were used was presented to the student teachers. Each strategy was identified by a number. Students were asked to organize the six oral CF strategies from the one that they thought to be the most effective to the one that they thought to be the least effective. They were also asked to explain their choices concerning the choices of the "most effective" and the "least effective" strategies, by their points of view.

STA Answers:

Figure 1 - STA answers

\begin{tabular}{|ll|}
\hline Most effective & Recast \\
& Metalinguistic Feedback \\
& Repetition \\
& Elicitation \\
& Clarification Request \\
Least effective & Explicit Correction
\end{tabular}

Source: Research data

When STA was asked why he sees recast as the most effective oral CF strategy, he answered that: "por que o professor não dá a resposta assim de cara. Ele comenta, né, fala sobre a resposta do aluno de uma maneira assim, bem 'descontraída', né... e usando a forma gramatical correta, e 
daí o aluno já percebe e ele mesmo corrige na fala seguinte."

When he was asked about his choice of explicit correction as the least effective one, he answered that: "E a primeira [explicit correction] eu achei a pior por que o professor ele meio que não explicou nada, ele só falou assim 'não é assim, é assado!'. Tipo, quem não tem conhecimento, sei lá, a pessoa [aluno] pode voar demais nisso.”

STB answers:

Figure 2 - STB answers

$\begin{array}{|ll|}\text { Most effective } & \text { Recast } \\ & \text { Retalinguistic Feedback } \\ & \text { Elicitation } \\ & \text { Clarification Request } \\ \text { Least effective } & \text { Explicit Correction }\end{array}$

Source: Research data

When STB was asked why he sees recast as the most effective OCF strategy, he answered that: "Because this one (recast) is implicit and it doesn't put students on the spot." Concerning his choice of explicit correction as the least effective strategy, he completed his thought stating that on the other hand, "this one (explicit correction) put the student on the spot."

Lastly, each student teacher was asked to watch, individually, a video segment of their own classes in which the use of oral corrective feedback was identified. After that, they were asked to make any comments that they thought to be pertinent, concerning the video segment presented to them.

STA was presented to a video segment of his own class in which a student questioned him about the fact that he corrected a mistake she made, concerning the use of specific time expressions with the present perfect tense to talk about experience, as "Only I have lost my umbrella The student questioned the student teacher because, according to her, another student made the same mistake and the student teacher did not correct him. About this video segment, STA said that:

"Na aula anterior eu tinha iniciado o assunto present perfect e como é de conhecimento geral é um assunto bem complicado para os estudantes, eu expliquei sobre a relação gramatical dele com palavras que denotam tempo e que não poderiam aparecer juntas, o livro também chama atenção para isso. Eu sabia que alguém formaria uma frase usando alguma expressão ou palavra que indicasse tempo, no caso a aluna usou today e eu não a corrigi porque eu já havia falado sobre e esperei que algum outro aluno 'levantasse a voz' pra apontar o erro, pois eu estava confiante que aquela palavra [today] ia chamar a atenção deles pelo tanto de exemplos que fora dado na aula anterior."

STB was presented to a video segment of his own class in which one of his students mispronounced the stressed syllable in the word "comfortable". He tried to let the students aware of the mistake by providing them with metalinguistic feedback. After noticing that the student would not be able to pronounce the word correctly, he provided him with explicit feedback, telling the student the correct pronunciation. About this situation presented in the video, STB said that: 
"Eu sempre tentava ativar o conhecimento prévio deles pra chegar num tópico em inglês, nesse caso, a pronuncia da palavra comfortable. Eu gosto de perguntar e fazer eles pensarem em vez de dar a resposta de mão beijada."

\section{DISCUSSION}

The OCF strategies most used in both the EFL and the K-12 settings were explicit correction, metalinguistic feedback and recast, being these strategies far more used than the other ones. Table 4: The use of OCF Strategies - EFL setting x K12 setting
C F strategies
EFL course setting
K12 school setting

\begin{tabular}{|c|c|c|}
\hline Explicit correction & 17 & 27 \\
\hline Metalinguistic Feedback & 8 & 3 \\
\hline Clarification Request & 4 & 2 \\
\hline Recast & 2 & 11 \\
\hline Elicitation & 2 & 1 \\
Repetition & 1 & 46 \\
\hline TOTAL & 34 & \\
\hline
\end{tabular}

Source: Resēarch data.

On the EFL setting, for example, while the use of explicit correction was identified 17 times, the use of clarification request, recast, elicitation and repetition (all together) were identified 9 times. On the k-12 setting, the use of explicit correction was identified 27 times, while the use of metalinguistic feedback, clarification request, elicitation and repetition were identified 8 times.

In an overall consideration of both settings, there was use of explicit correction 44 times, followed by recast, which was used 13 times. This significant difference suggests that both student teachers observed tend to use direct/explicit feedback strategies much more than indirect/implicit strategies.

However, when the student teachers were asked to organize the OCF strategies based on what they believed to be effective or not, both student teachers identified explicit feedback as the least effective one and recast as the most effective.

Research studies have already emphasized that recast is one OCF strategy that seems to be less threatening for the learner, since it is implicit and less intrusive (TROFIMOVICH et al., 2007 apud RASSAEI, 2013). This finding corroborates with what the student teachers interviewed for the research mentioned. On the other hand, recast could also be considered imprecise, since students could not notice that teachers are correcting a mistake or just reinforcing what he or she has just said.

Explicit correction, even if considered too intrusive, since the teacher refers directly to the student mistake, could also be an effective strategy. For example, on a research about learners' perceptions on CF, Rassaei (2013) found out that a group of students that was exposed to explicit correction performed better than the group exposed to recast. The same research mentioned the aspect that students who were exposed to explicit correction seemed to perceive more that they were being corrected than the ones exposed to recast.

Recast and Explicit correction, despite of being classified as different types of strategies (re- 
cast being considered indirect, while explicit correction is considered direct) share one common aspect: both of them usually do not give the appropriate opportunity for the learner to reformulate his or her erroneous utterance. In other words, there is no opportunity for uptake or negotiation of form. Research has shown that when CF is followed by uptake, chances are that the corrective feedback would be accurately perceived (MACKEY et al., 2000; EGI, 2010 apud RASSAEI, 2013).

During the classes observed, one strategy the student teachers used when dealing with oral mistakes was writing students' erroneous utterances on the board, which was also in accordance with what both STA and STB described during the follow up interview. The positive aspects of this strategy, according to Brandl $(2008$, p. 163) is that it gives more time for the student to notice a mistake while, at the same time, this strategy also allows for a deeper processing. On the other hand, it could also be time consuming and an inducing strategy that triggers anxiety. As a possible solution for this dilemma, teachers should discuss their error correction strategies with their students individually.

During the interviews, when asked about how corrective feedback in an EFL classroom was seen, STA says that it is necessary, but adds that he does not know how to deal with correction. After seven years of teaching practice, one would assume that STA might have an idea of how to deal with mistakes inside an EFL classroom, although he might not be aware of the cognitive dimensions of these processes (what he knows, believes and thinks about the use of CF).

The results found during this research also demonstrated that OCF could be inconsistent, as Ellis (2009) discussed. It could be noticed when STA corrected one student but did not correct other students' mistakes concerning the use of the present perfect tense.

In addition, when STB says that he does not like to keep correcting his students because it might "upset" them, when he says that CF build up students' "confidence" or that the use of recast could help the students not to be afraid of speaking, he is clearly taking into consideration his students' affective filters (feelings and emotional characteristics). Such comments are in accordance with Brandl (2008) when he emphasizes that learners' affective reactions should always be taken into consideration by teachers when giving CF, since students' attitudes towards correction are a determinant factor for the effectiveness of the CF.

Concerning the difference between the amount of time spent on the use of OCF on the EFL course setting $(11,4 \%)$ and the K-12 school $(10,9 \%)$, even when there were more uses of OCF strategies in the school setting, we could take into consideration what STB said about the school setting that "the focus in schools is not for students to reach perfect pronunciation". This statement might be related to some important factors such as time constraints, since k-12 regular schools usually offer a 50-minute class per week, while EFL courses usually offer two 100-minute class per week, what could clearly give the teacher more time to focus on the development of different skills. In addition to that, there is also a common belief shared by teachers and students that it is not possible to learn English at Brazilian schools, especially the public ones (see COELHO, 2005).

Although peer feedback is not the focus of this research, it was an emerging theme on the interview. When asked about the use of corrective feedback strategies, STA answered that "Eu não gosto de botar os alunos pra se corrigirem entre si", not describing why he did not like to do it. This kind of belief reinforces the concerns that teachers usually have about peer feedback, relating students' low proficiency on a L2 to the way they would provide feedback to their classmates (SHULIN AND ICY, 2016, pp. 483). Research on Peer feedback, however, has shown that not only the students giving feedback, but also the ones receiving might benefit from it (SIPPEL AND CARRIE, 2015).

\section{FINAL REMARKS}

OCF is unquestionably an essential factor when dealing with the learning and teaching of a foreign language, and both Student teachers interviewed seemed to be aware of the importance in

https://periodicos.unifap.br/index.php/letras

Macapá, v. 10, n. 1, $1^{\circ}$ sem., 2020 
providing OCF in a classroom.

Concerning one of the objectives of this research, which was to investigate how OCF takes place in two different classroom settings, the results found that both STA and STB tend to use direct/explicit strategies (e.g. Explicit Correction) more than indirect/implicit strategies (e.g. recast) when dealing with oral correction in both EFL and K-12 settings.

In addition, it was found that there was more use of OCF strategies in the K-12 setting than the EFL setting. However, the amount of time spent on OCF was more frequent in the EFL setting, what could be explained by factors such as the time constrains faced by STB.

Regarding the second objective, which was inquire what student teachers' beliefs on OCF are, the results suggest that the student teachers interviewed see recast as the most effective strategy, while they see explicit correction as the least effective strategy. Also, they believe that students should not be over corrected, because it could lead them to be upset or afraid of speak. On the contrary, both student teachers see explicit correction (the OCF strategy they most used) as one strategy that "put the student on the spot". Lastly, both of them consider display students' mistakes on the board as an effective strategy of correction, even when dealing with oral production.

In conclusion, although OCF is considered an important factor in language teaching, student teachers might not feel prepared enough to deal with it inside the classroom. Such beliefs they might have about CF should be taken into consideration during the development of the programmes of the undergraduate teaching courses they are taking, since research has already shown that when student teachers beliefs are ignored, the programmes might be less effective at influencing these (KETTLE \& SELLARS, 1996; WEINSTEIN, 1990 apud BORG, 2009).

Due to time limitations, the student teachers could not be asked to talk about the discrepancies found between their beliefs and what happened inside the classroom, what is known as selfconfrontation (See VIEIRA AND FAITA, 2003). Further research about student teachers' beliefs on OCF using self-confrontation is suggested, as well as research focusing on uptake or students' beliefs on OCF.

\section{REFERENCES}

ANGELO, T. A.; CROSS, K. P. Classroom Assessment Techniques: A Handbook for College Teachers. Second Edition. Jossey-Bass, Inc., Publishers, 1993.

BARTRAM, M.; WALTON, R. Correction: mistake management. Australia: Language Teaching Publications, 2004.

BORG, S. Teacher cognition in language teaching: A review of research on what language teachers think, know, believe, and do. Language Teaching, 36 (2). pp. 81-109. 2003.

BRANDL, K. Communicative language teaching in action. Upper Saddle River, N.J: Pearson Prentic Hall, 2008. BROWN, H. Principles of language learning and teaching. White Plains, NY: Pearson Longman, 2008.

COELHO, H. H. É possivivel aprender inglês na escola? Crenças de professores e alunos sobre o ensino de inglês em escolas públicas. Dissertação (Mestrado em Estudos Linguísticos) - Universidade Federal de Minas Gerais, Belo Horizonte, 2005.

EDGE, J. Mistakes and correction. London: Longman, 1997.

ELLIS, R. Corrective Feedback and Teacher Development. L2 Journal, Vol. 1 (n. 01), p. 3 - 18. 2009.

HARMER, J. The practice of English language teaching. Harlow: Pearson Education, 2013.

KIRKGÖZ, Y. et al. Corrective Feedback in Primary EFL classrooms in Turkey. American International Journal of Social Science, Vol. 4 (n. 3), P. 90 - 101. Junho, 2011.

LARSEN-FREEMAN, D.; ANDERSON, M. Techniques and principles in language teaching. Oxford: Oxford University Press, 2011.

LIGHTBOWN, P; SPADA, N. How languages are learned. Oxford: Oxford University Press, 2013.

LIMA JR, R.M. ESL/EFL Oral Error Feedback (testyourself). 2011. (2m54s). Available on: < https:/ /www.you tube.com/watch?v=VFVSQTNUxtc>. Accessed on: April, 07. 2018.

LYSTER, R. Learning and teaching languages through content. Amsterdam: John Benjamins Pub., 2007.

MENTI, M. EFL Teachers' Choices for Different Types of Corrective Feedback. In: SARMENTO, Simone (Org.). Ensino do Inglês como Lingua Estrangeira: estudos e reflexões II. Porto Alegre: Apirs, 2009, pp. 191-203 
RASSAEI, E. Corrective Feedback, Learners' Perceptions, and Second Language Development. System: An International Journal of Educational Technology and Applied Linguistics, Vol.41(2). 2013. pp.472482

SHRUM, J.; GLISAN, E. Teacher's handbook. Boston: Heinle, 2010.

SHULIN, Y; ICY, L. Understanding the Role of Learners With Low English Language Proficiency in Peer Feedback, of Second Language Writing. TESOL Quarterly, 2016 June, Vol.50(2), pp.483-494

SIPPEL, L; CARRIE N., J. Teacher vs. Peer Oral Corrective Feedback in the German Language Classroom. Foreign Language Annals, December 2015, Vol.48(4), pp.688-705

UR, P. A course in English language teaching. 17th ed. Cambridge, 2009.

VASCONCELOS NETO, Jaime José de. Student teachers' beliefs on oral corrective feedback. 2018. 33f. - TCC (Artigo) - Universidade Federal do Ceará, Curso de Letras, Língua Inglesa e suas Literaturas, Curso de Graduação em Letras Inglês, Fortaleza (CE), 2018.

VIEIRA, M.; FAÏTA, D. Quando os outros olham outros de si mesmo: reflexões metodológicas sobre a autoconfrontação cruzada. Polifonia, Cuiabá, n. 7, p. 27-65, 2003. Available on: < http://www.periodicoscientificos.ufmt.br/ojs/index.php/polifonia/article/viewFile/1137/901>. Accessed on: November, 20, 2018. 